\title{
Overcoming Financial and Institutional Barriers to TOD: Lindbergh Station Case Study
}

\author{
Eric Dumbaugh
}

\begin{abstract}
While transit-oriented development has been embraced as a strategy to address a wide range of planning objectives, from minimizing automobile dependence to improving quality of life, there has been almost no examination into the practices that have resulted in the actual development of one. This study examines Atlanta's Lindbergh Station TOD to understand how a real-world development was able to overcome the substantial development barriers that face these developments. It finds that transit agencies have a largely underappreciated ability to overcome the land assembly and project financing barriers that have heretofore prevented the development of these projects. Further, because they provide a means from converting capital investment into positive operating returns, this study finds that development projects provide transit agencies with a unique means of overcoming the capital bias in funding apportionment mechanisms. This latter factor will undoubtedly play a key role in increasing the popularity of transit-agency sponsored TOD projects in the future.
\end{abstract}




\section{Introduction}

Transit-oriented development (TOD), which seeks to encourage transit and walking as a travel mode by clustering mixed-use, higher density development around transit stations (Calthorpe 1993), has become popularly embraced as a strategy for mitigating a host of social ills, such as sprawl, automobile dependence, travel congestion, air pollution, and physical health, among others (Belzer and Autler 2002; Cervero et al. 2002; Frank et al. 2003). Despite these potential benefits, there has been little examination into the development practices that result in the actual occurrence of a TOD.

The literature addressing the topic of TOD implementation typically details developmental and regulatory barriers to TOD (Boarnet and Compin 1999; Belzer and Autler 2002; Leinberger 2001; SMARTRAQ 2001; Cervero et al. 2002), and then concludes by providing general guidelines and best practices, such as "Collaboration Is Key" (Renne and Wells 2002) or "Revise Development Codes" (Arrington 2003). While such "best practices" are useful as a conceptual starting point for encouraging TOD, they fail to consider the complicated financial and institutional arrangements needed to finance and construct these developments.

The absence of real-world project information is widely recognized as one of the major deficiencies in the literature on TODs. Indeed, the most comprehensive literature review on TODs to date, published by the Transit Cooperative Research Program, concludes that:

Research into the institutions, politics, methods, and impacts of TOD and TJD [transit joint development] is needed now more than ever... There is a huge pent-up demand for best-case practices that others can imitate and learn from.

(Cervero et al. 2002, 89)

To help address this research need, this study provided a detailed examination into the financial and institutional practices that led to the development of a TOD project. Specifically sought is an understanding of TOD implementation strategies that can be used to inform development strategies in other regions. For many advocates of transit-oriented design, this information is essential for understanding how to move TOD from a development concept to a development reality. 


\section{Study Methodology}

This research employs a case study approach to better understand how project finance and land assembly barriers can be meaningfully overcome in practice. By examining a real-world development, this study is able to move beyond theoretical best practices. Nevertheless, the use of a case study as a research approach necessarily raises questions regarding the appropriateness of the identified case in meeting the stated research objective, as well as the ability to generalize from an individual observation. Both of these research concerns are addressed below.

\section{Case Selection}

Several factors led to my selection of the Lindbergh Station TOD for this analysis. First, many of the projects that have been heralded as TOD successes are in fact nothing of the sort. They either lack functional integration to nearby transit service, and thus are, in fact, "transit-related developments" (Belzer and Autler 2002) or else they, like Laguna West, were designed to support future transit service, but currently lack a transit connection (Calthorpe 1993). While such developments are notable, they cannot be adequately understood as models on which to understand TOD implementation since they are not fully realized TODs. Once one distinguishes these types of developments from actual TODs, very few representative developments are available for study.

Second, MARTA's Lindbergh Station Development was the first development selected to pilot the Federal Transit Administration's 1997 Policy on Transit Joint Development, giving it intrinsic value for this analysis. The FTA's policy revisions were intended to encourage transit agencies to take a more active role in the development of station-area lands. Lessons emerging from this pilot project would seem to be of great practical importance for other transit agencies throughout the United States.

Third, while several studies on transit-oriented developments have asserted that transit agencies can play an important role in the implementation of these projects (Porter 1997; Cervero et al. 2002), there has been little examination into the nature of this role. As described in the literature, this role is largely that of the advocate (Cervero et al. 2002; Belzer and Autler 2002). These assertions are principally made on theoretical grounds, rather than from detailed examinations into the practices of transit agencies. I believed that a focused study on a transit agency-sponsored project was essential for adequately understanding the role these agencies could play. 
Finally, and perhaps decidingly, my institutional connections with the planning agencies in the Atlanta region afforded me a high level of access to the key actors involved in making the decisions that resulted in the Lindbergh TOD. Beyond their willingness to both be interviewed and to respond to subsequent follow-up questions, these individuals also allowed me to review highly sensitive internal documentation and materials, materials which would have otherwise been impossible to obtain. Access to this material allowed me to understand this development in a level of detail that would have been impossible in other areas.

\section{Addressing Generalizability}

Generalizability is often the major design shortcoming of case study research (Yin 2003). To ensure that the results of this study are relevant to other areas and regions, this study is conducted with an eye toward identifying those policies and practices that could be transferred to address similar barriers in other regions. In this study, the Lindbergh development was examined to determine the following:

- What were the development incentives of the project sponsor?

- How did the project overcome land assembly barriers?

- How did the project overcome financial barriers?

- What financial and ridership benefits does the project create for its publicsector partners, if any?

The answers to these questions are of great relevance to other areas that are contemplating a TOD development strategy.

\section{The Lindbergh Station TOD}

In 1997, the Metropolitan Atlanta Rapid Transit Authority (MARTA) announced its plan to develop a 47-acre site surrounding its Lindbergh Station into a transitoriented development. The site seemed ideal for the project. Located along Piedmont Avenue between the City of Atlanta's rapidly growing Midtown and Buckhead districts, and with superior access to the region's downtown and Perimeter Center employment hubs, the parcel appeared ripe for redevelopment. At the time of the announcement, the Lindbergh station area consisted of aging, low-density strip development, and MARTA's landholdings around its Lindbergh station was serving primarily as a park-and-ride lot for local commuters (see Figure 1). 


\section{Figure 1. The Lindbergh Station-Area (top) and Its Location in the City of Atlanta (bottom)}

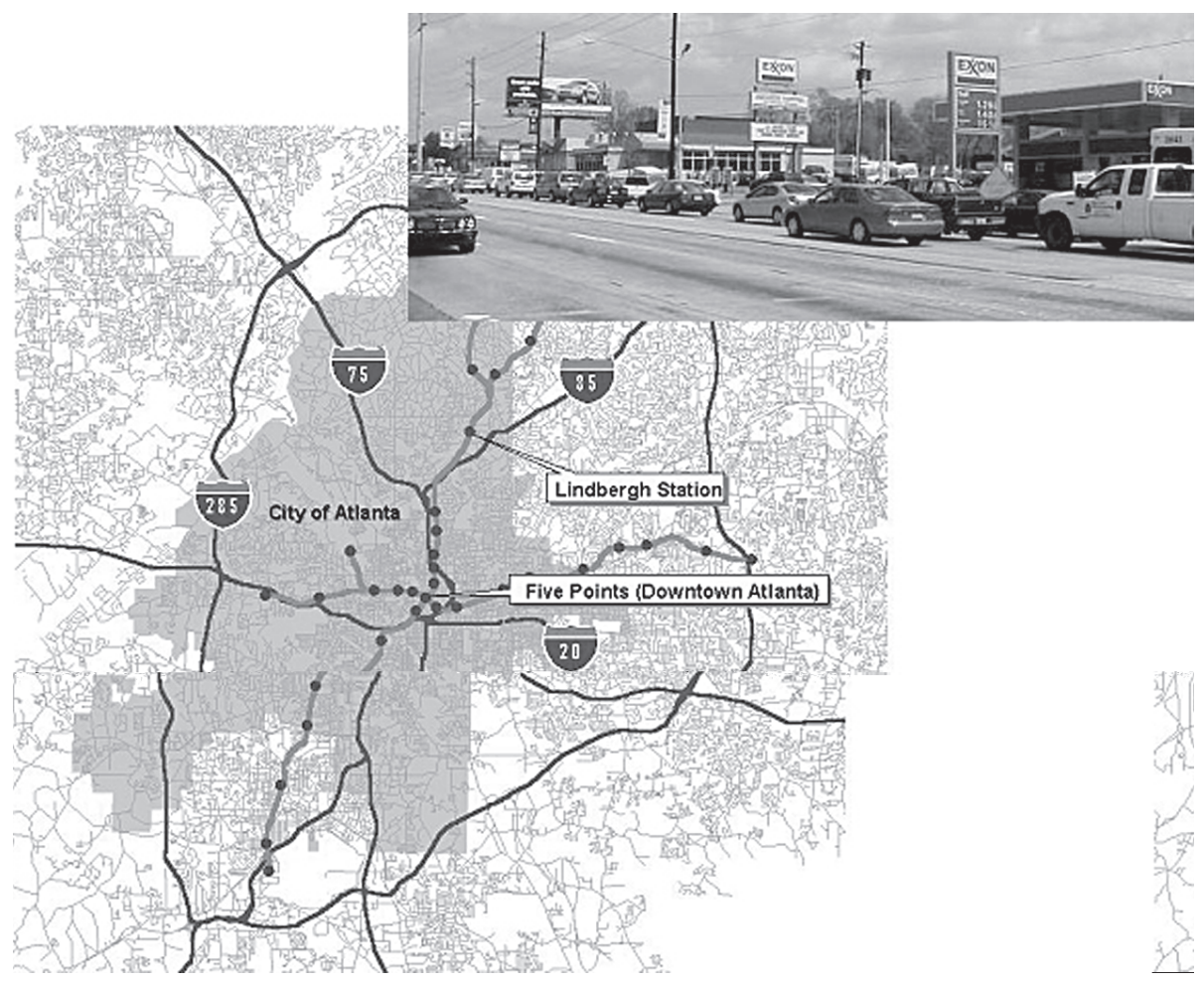

While the project plan went through several iterations, MARTA's final plan for the site would include roughly 2.5 million square feet of commercial office space, 2.2 million of which was reserved for BellSouth, 300,000 square feet of retail, roughly 1,300 residential units, as well as a 160-room hotel (see Figure 2 and Table 1). 
Table 1. Land-Use Elements of the Final Lindbergh TOD

\begin{tabular}{|lcc|}
\hline Component & Size & Partner \\
\hline BellSouth Office & $2,200,000 \mathrm{sq} \mathrm{ft}$ & BellSouth \\
Speculative Office & $225,000 \mathrm{sq} \mathrm{ft}$ & Federal Realty \\
Retail & $300,000 \mathrm{sq} \mathrm{ft}$ & Federal Realty \\
Hotel & 160 rooms & Federal Realty \\
Rental Residential & 916 Units & Post Properties \\
For Sale Residential & 382 Units & Post Properties \\
\hline
\end{tabular}

Figure 2. The Final Lindbergh Station Site Plan
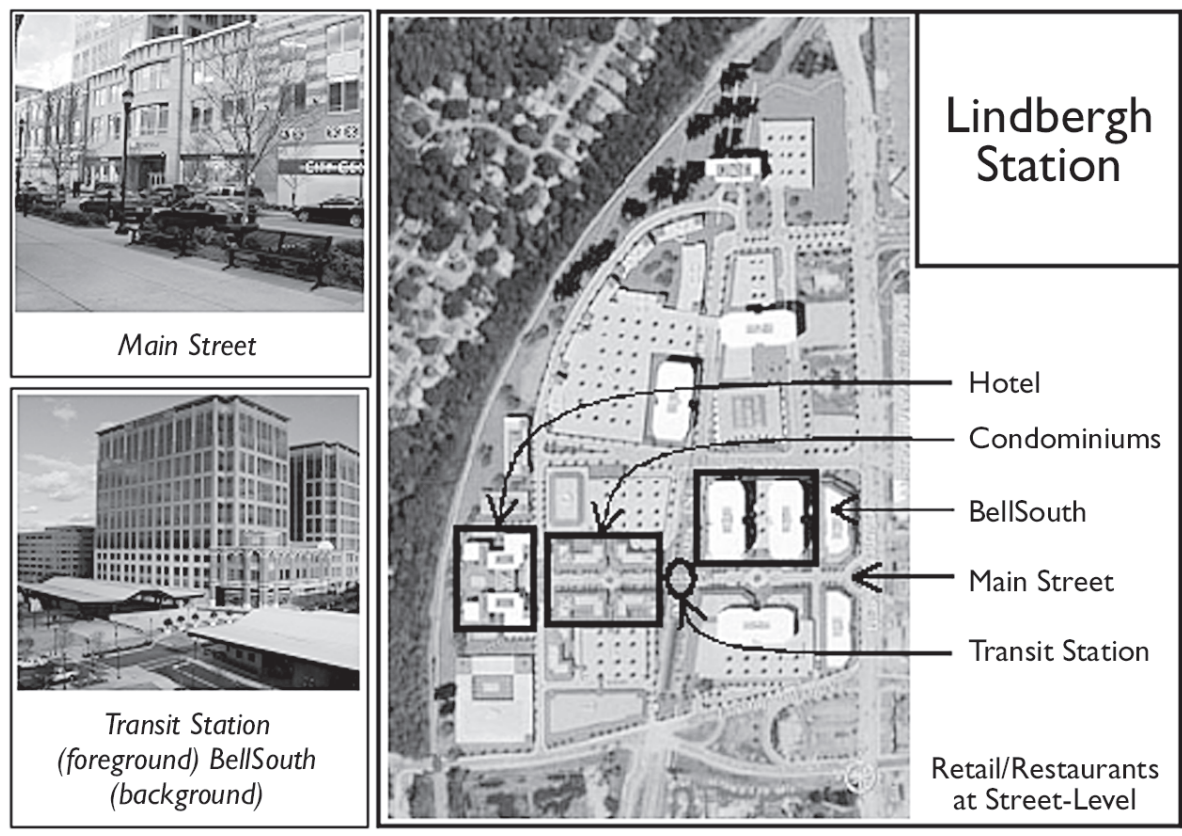


\section{Overcoming Developmental Barriers}

This study examines the Lindbergh TOD across four major areas. First, it identifies the sponsor for the project, as well as their incentives for encouraging the development. Second, it considers how the project overcame the land assembly barriers that hinder these developments. Third, it outlines the mechanism used to address the capital infrastructure costs of the development's financial barriers. Finally, this study considers the financial benefits the project generates for its public-sector partners in return for their investment in the development.

\section{Project Sponsor Incentives}

In the case of the Lindbergh development, MARTA was not only the champion of the project, it was the project's primary sponsor. MARTA's interest in encouraging TOD is obvious: Each additional rider increases the agency's bottom line. The agency has an inherent interest in encouraging station-area developments that funnel new riders into the transit system. What makes MARTA's involvement in the Lindbergh development unique is that, for the first time, a transit agency took the primary role in developing the properties surrounding a transit station.

The reason for this unique shift is not due to any unique innovation on the part of MARTA itself, but instead due to recent revisions in federal policy. While the Common Grant Rule had previously prevented transit agencies from developing federally assisted properties for purposes other than those directly related to transit, the FTA had recently revised this policy to permit these landholdings to be developed into transit-oriented developments. MARTA's landholdings around its Lindbergh station - much of which had been acquired with federal aid-were suddenly available for development. Rather than use this regionally central location as a park-and-ride lot, MARTA was suddenly presented with the opportunity of transforming it into a significant point of both transit origin and destination.

While MARTA's interest in the project is clear, it leads to a broader consideration of the role transit agencies can play in the development of similar projects. Considering the role of transit agencies more generally, it is obvious that they, more than either local governments or private developers, are the logical sponsors of such projects (Cervero et al. 2003). While private developers are motivated by net profit, and municipalities by increased tax revenues, transit agencies receive a direct benefit from each new system rider. To successfully achieve the agency' transit ridership objectives, transit agencies have a strong incentive to encourage mixed-use, pedestrian-oriented developments at station ends that enable individuals to ac- 
complish a variety of travel objectives without the use of an automobile. Pedestrian-friendly design and the related benefits it can generate are consequently of great practical importance to the agency's measurement of success; any deviation from these development objectives detracts from the agency's overall performance.

\section{Land Assembly}

Not only did federal policy revisions provide MARTA with the incentive for undertaking joint development projects, they provided it with the means for overcoming land assembly barriers as well. Transit agencies typically accumulate excess landholdings as part of developing their regional transit system; ${ }^{2}$ the FTA's Policy on Transit Joint Development suddenly made these formerly "undevelopable" lands available for development, thus, at least in part, removing major land assembly barriers to TODs.

The use of these properties was not unrestricted, however. As a criterion for evaluating development projects, the FTA introduced the concept of highest and best transit use. The concept is similar to the theory applied in conventional real estate analyses, except transit effectiveness is factored into the analysis. As defined by the FTA, the highest and best transit use is "that combination of residential, retail, commercial and parking space that results in the highest level of transit support from a combination of project revenues and increased ridership" (Federal Register 1997). While no minimum project benchmarks have been established, the FTA does require a proposed development to meet an informal three-part test (Marx 2002):

1. Is the development functionally related to transit?

2. Does the development generate revenue for the transit provider?

3. Does the development improve access to the system, accounting for the affects of new riders?

In short, development projects that generate a net profit to the transit provider and that demonstrate meaningful increases in system ridership are exempt from federal repayment obligations. As a result, MARTA suddenly had a large tract of developable land, and a strong incentive to develop it.

An interesting, and perhaps unrecognized aspect of the FTA's joint development policy was that it not only absolved transit agencies from their obligations for repaying the federal government for federally acquired properties, it also provided a means for utilizing federal capital funds for acquiring new landholdings for TOD projects as well. Since the policy revision regarded lands used for joint develop- 
ment projects as transit capital investments, transit agencies could now apply for federal capital funding to acquire additional properties needed for a proposed TOD project. Indeed, MARTA, as the first agency selected as part of the FTA's pilot program for its joint development policy, utilized this flexibility to acquire $\$ 1.6$ million in new funds that were used not only for project planning, but also for the acquisition of 1.5 additional acres for the project (MARTA 1999).

\section{Financing Mechanisms}

Federal policy revisions gave MARTA both the incentive and the ability to undertake the Lindbergh development. What was by no means clear, however, were the financial arrangements that would enable the development to be constructed.

Under MARTA's development plan, the agency would finance the project's streetscape, sewer, and structured parking facilities, thereby absorbing the project's front-end capital needs, as well as most of the project's risks. In return, MARTA's development partners agreed to sign 99-year ground leases on the property, and to construct their buildings in conformity with MARTA's master plan for the site.

To fund its share of this arrangement, the MARTA board of directors authorized an $\$ 81$ million bond issuance (Vespermann 2001). Thus, in one fell swoop-a simple majority vote of its board of director-MARTA was able to bypass the financial barriers that have traditionally made the financing and implementation of these projects so difficult. While it is tempting to immediately herald this development as a success, several questions emerge. First, what was the means by which MARTA was able to make such a substantial public commitment without subjecting the bond issuance to a public referenda? Second, what are the actual benefits that this project creates for MARTA? Transit agencies are not principally land developers, yet, in the case of the Lindbergh development, MARTA has elected to undertake a project that the private sector, left to its own financing practices, would not.

This necessarily raises questions about the financial arrangement underpinning this development. If the Lindbergh TOD is to serve as a model for subsequent transit joint-development projects, what revenues does the project generate in return for MARTA's investment? The following sections detail what is perhaps of greatest interest to TOD advocates. First, it examines the institutional mechanisms that enabled MARTA to finance its share of this arrangement. And, second, it details the new ridership and developmental revenues that the project is expected to generate in return for MARTA's $\$ 81$ million investment. 
Transit Agencies as Public Authorities

The key to understanding MARTA's ability to finance requires an understanding of the historical creation of transit agencies. Transit service was originally provided not by public agencies, but by private transit operators (Warner 1978; Jackson 1985). The advent of the private automobile and the lower-density development patterns that it generated made providing this service unprofitable, forcing private transit companies to discontinue service (Calthorpe 1993; Duany et al. 2000; Glacel 1983; Jackson 1985). The concept of "public transit" was the result of the realization that transit service was essential to meeting regional mobility needs, and thus merited public subsidies to continue its operation. While the public sector could have decided to provide this service directly or to contract this service to private operators, they instead opted to create special "public authorities" 3 that were authorized with the ability to construct and operate transit systems.

Public authorities are unique institutions created through state enabling legislation. While they are funded through public revenues, they resemble private corporations more than they do any purely public-sector entity. Public authorities are governed by a board of directors whose membership is typically not determined through public proceedings such as a general election, but through appointees specified in its enabling legislation (Axelrod 1992). ${ }^{4} \mathrm{Be}-$ cause of their semiprivate characteristics, the actions of public authorities are typically not subject to public review unless they are explicitly required to do so in their enabling legislation, or unless they use federal funds for a project that has explicit public involvement requirements.

Despite their private-sector characteristics, the charters under which transit authorities are created typically supply them with many of the powers reserved for public agencies, including the ability to exercise eminent domain, to create laws and establish a police force, ${ }^{5}$ as well as the ability to finance projects using bonds backed by public revenues. Unlike municipalities however, transit authorities are not required to submit bond issuance to a public referendum (Walsh 1978). In practice, as Robert Caro observed in The Power Broker, public authorities have the ability to function as a "sovereign state" (623), making transit authorities, such as MARTA, potentially powerful forces in regional development. Indeed, MARTA's ability to synthesize its institutional power as a 
public authority is key to understanding its ability to finance the Lindbergh TOD.

The major financial barrier to TODs, from the perspective of the private-sector developer, is that current financial evaluation methodologies, such as discounting and internal rate-of-return, favor short-term investments, typically over periods of five to seven years. Because TODs have high front-end capital costs, these developments typically take longer than seven years to mature, making them undesirable from an institutional lender's perspective (Leinberger 2001; Danielsen et. al., 1999; SMARTRAQ 2001).

As a public authority, MARTA is consequently able to use dedicated public revenues to backstop low-interest bonds. Thus, the agency does not need to conform to conventional lending practices to finance a project, nor does it need to seek public approval for their use. MARTA can consequently finance the Lindbergh development's infrastructure, and hence most of its risks, thereby offering its private-sector partners with the ability to distinguish their products in the market without accepting the corresponding risk associated with substantial front-end infrastructure investments. While this resolves an important barrier to TODs, it does not ensure that the project is a meaningful investment of public resources. The key question remains: What are MARTA's returns for this investment?

\section{Project Benefits}

Before analyzing the project's investment returns, it is important to first specify the sources of revenue the project will generate. First, and most obviously, MARTA's investment will generate revenues from ground leases and condominium sales. Nevertheless, evaluating the project solely on the returns from these sources would neglect MARTA's real incentive in investing in the project-the generation of new system riders. Correspondingly, the following analysis accounts for the projected revenues that will occur from new system ridership in addition to land development revenues.

Financial Assumptions

Reviewing the financial practices that underpinned the Lindbergh development proved difficult. While MARTA staff was largely cooperative in providing basic information on the Lindbergh project, contractual agreements with its development partners prohibited MARTA from disclosing the details of its 
financial arrangements. Still, certain elements, such as the application it submitted to the FTA and its development-phasing plan, were public record, and MARTA was willing to provide its financial assumptions regarding transit ridership, as well as its anticipated aggregate revenues for the project at completion. Using these data sources, it was possible to approximately reconstruct the development's financial model.

Project revenues from new transit ridership were approximated by making basic assumptions about the number of employees and residents for each of the project elements, as well as their trip-making behavior, ${ }^{6}$ while accounting for vacancy rates (Table 2), and then using MARTA's transit capture ${ }^{7}$ (Table 3 ) and farebox assumptions to arrive at transit ridership revenues. MARTA's financial assumptions assumed that the base fare of $\$ 1.75$ would be reduced by 25 percent to account for the use of special fare rates, such as monthly passes. Further, MARTA projected a consistent 2 percent annual fare increase through the life of the project.

\section{Table 2. Ridership Assumptions}

\begin{tabular}{|lcccc|}
\hline Project Element & $\begin{array}{c}\text { Vacancy } \\
\text { Rate }\end{array}$ & Unit & $\begin{array}{c}\text { Annual } \\
\text { Travel Days }\end{array}$ & $\begin{array}{c}\text { Annual } \\
\text { Trips }\end{array}$ \\
\hline BellSouth Office & $0 \%$ & 150 s.f. per employee & 244 & $7,157,496$ \\
Office & $5 \%$ & 150 s.f. per employee & 244 & 695,400 \\
Retail & $5 \%$ & 52 persons per 1,000 s.f. & 360 & $11,737,440$ \\
Hotel & $5 \%$ & 1.1 persons per room & 360 & 101,152 \\
Residential & $5 \%$ & 1.3 persons per unit & 360 & $1,155,600$ \\
\hline
\end{tabular}




\section{Table 3. Estimated Transit Ridership for Trips Generated by the Lindbergh TOD}

\begin{tabular}{|lcccc|}
\hline Project Element & Element Size & $\begin{array}{c}\text { Annual } \\
\text { Trips }\end{array}$ & $\begin{array}{c}\text { Transit } \\
\text { Capture }\end{array}$ & $\begin{array}{c}\text { Transit } \\
\text { Riders }\end{array}$ \\
\hline Bellsouth Office & $2,200,000 \mathrm{sq} \mathrm{ft}$ & $7,157,496$ & $30 \%$ & $2,147,246$ \\
Speculative Office & $225,000 \mathrm{sq} \mathrm{ft}$ & 695,400 & $10 \%$ & 69,540 \\
Retail & $300,000 \mathrm{sq} f t$ & $11,737,440$ & $5 \%$ & 586,872 \\
Hotel & 160 rooms & 101,152 & $10 \%$ & 10,152 \\
Residential & 1,298 units & $1,155,600$ & $10 \%$ & 115,560 \\
\hline
\end{tabular}

The joint development application MARTA submitted to the FTA indicated its intention to build 120 condominium units at the Lindbergh site, providing MARTA with conservative sales proceeds of $\$ 5$ million and placing the per unit proceeds at $\$ 41,667$. Later revisions to the development plan increased the number of units to 382. This analysis assumed that MARTA's per unit sales proceeds remained unchanged; revenues from condominium sales were determined by multiplying by $\$ 41,667$ by the number of units scheduled to be sold each development year.

Once values for these data points were determined, deriving estimates of ground lease revenues was simply a matter of subtracting transit ridership estimates and condominium sales from total revenues. While such an approach did not permit the revenues from specific project components to be identified, it nevertheless provided an approximate measure of aggregate revenues derived from ground leases. $^{8}$

\section{Project Revenues}

To finance the Lindbergh TOD, MARTA issued $\$ 81$ million in bonds to be repaid over a 30-year period at 4 percent interest, compounded annually. Because MARTA did not disclose the time periods at which these bonds would be issued, the following analysis assumes that the full $\$ 81$ million was issued on day one, to be repaid in equal annual payments of $\$ 4,684,238$ over the 30 -year period. Under this accounting scheme, MARTA's Lindbergh project will produce roughly $\$ 293$ million, in 2001 dollars, of new revenue during the 30-year period over which the project is financed. Less the cost of repaying the bonds, this provides MARTA with almost $\$ 153$ million in net new revenues (see Table 4 ). While such a return would seem profitable, on the surface, the longer-term period over which these returns are realized makes these benefits misleading. If one considers investing the same 


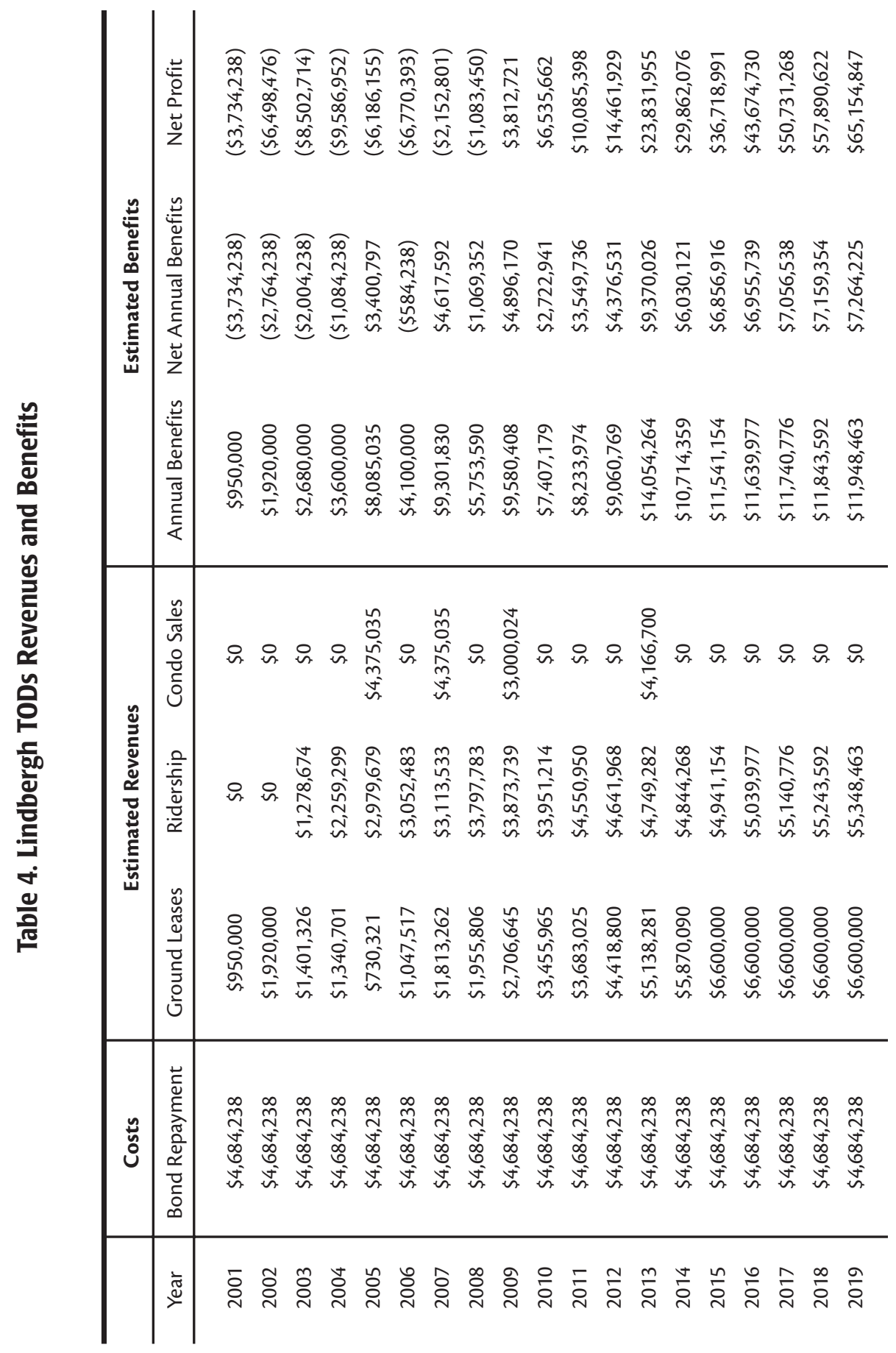




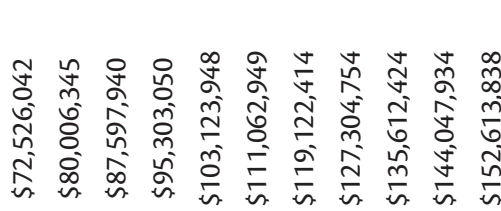

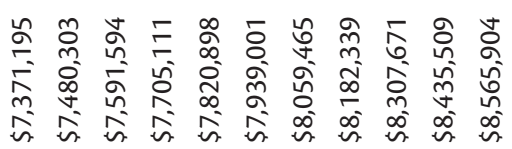

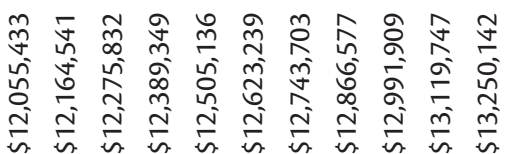

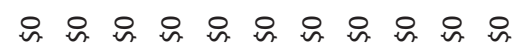

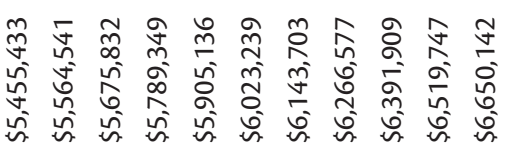

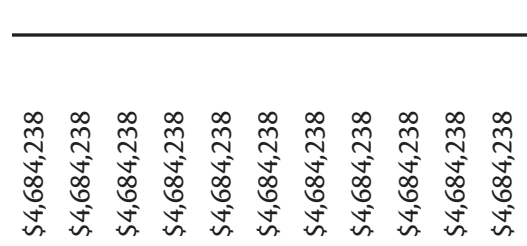

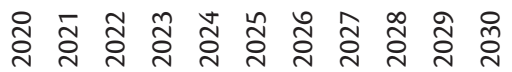


amount of money $-\$ 81$ million-in a savings account that yielded 5 percent per year, MARTA's returns over the 30-year cycle would be $\$ 350$ million-more than twice that realized by the Lindbergh development.

When one considers the time value of money, the Lindbergh project looks even less desirable. Assuming a generous discount rate of 4 percent and accounting for discounted costs and revenues, the net present value of the project at the end of the 30-year investment period is only about $\$ 71$ million $-\$ 10$ million less than MARTA's initial investment. MARTA's returns also do not account for the inherent risk of this development. These returns are based on the assumption that all of MARTA's revenue and ridership assumptions are realized. The failure of a project element to generate the anticipated financial returns can have a dramatic impact on the project's overall profitability. MARTA, by financing the infrastructure costs of this development, has largely underwritten most of the project's risks. High-risk projects should return high yields. Nevertheless, MARTA's annual yield on this investment is, under the best circumstances, only about 2.1 percent-well below national interest rates, despite the project's risks.

An issue that potentially compounds this problem is the project's performance over the short term. For MARTA, the Lindbergh station development operates largely at a loss through year six, although condominium sales help to offset the magnitude. The project only begins showing net annual benefits in its seventh year, and does not show a net profit until year nine (see Table 4). MARTA is currently running a $\$ 20$ million operating deficit that has forced the agency to cutback route frequency and to eliminate underperforming routes (Atlanta Journal Constitution 2001). The decision to undertake a major development project that operates at a significant net loss during this critical period, and that ultimately generates few long-term benefits seems at first confusing. Considering the relatively low yield on this high-risk investment, MARTA's decision to invest in the development makes little sense.

\section{Circumventing the Operations Dilemma}

Clearly, the key factor in MARTA's decision to undertake this project is not the project's overall profitability. The key lies in what the project secures for the agencya continuous, $\$ 13.3$ million annual revenue stream that will continue indefinitely. Development projects, such as Lindbergh, also provide a means to bypass the major financial hurdle that confronts transit agencies-operating costs. Understand- 
ing the financial significance of these projects requires a brief discussion of the financial structures of transit agencies.

When transit authorities are created, their enabling legislation allocates public funds to sustain them, but also specifies the apportionment that can be used for capital purposes, such as constructing new rail lines or purchasing buses, and that which can be applied to operations, which is the cost of actually providing transit service on a day-to-day basis. MARTA, for example, is funded by a 1 percent local sales tax that is split evenly between capital and operations ${ }^{9}$ (see Figure 3 ).

\section{Figure 3. MARTA Funding Allocations}

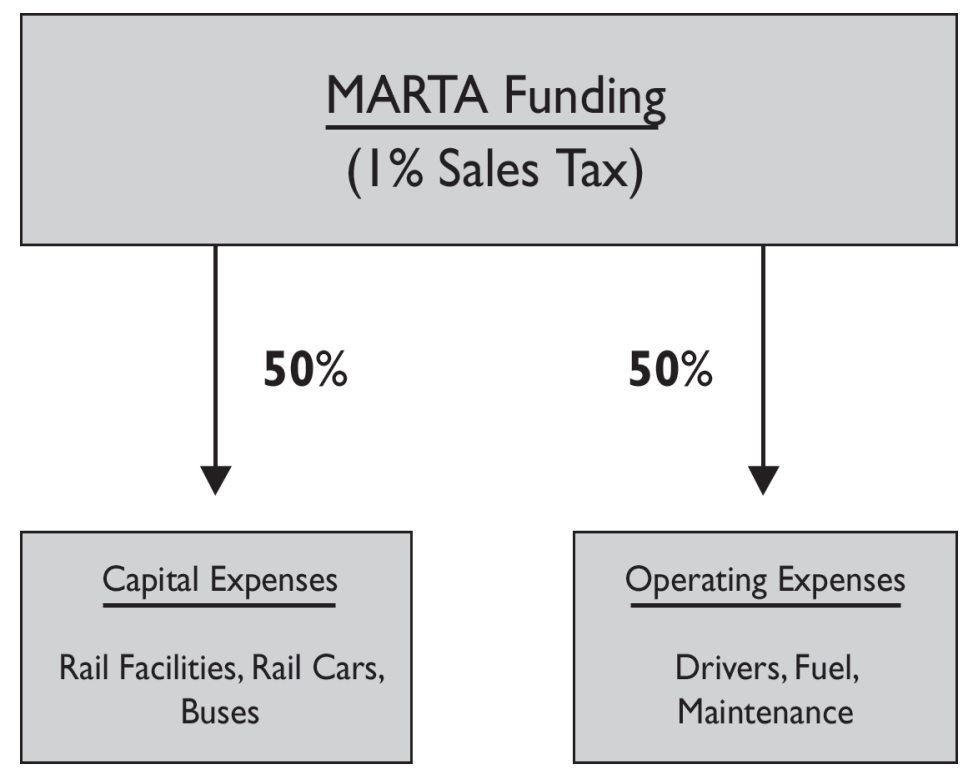

While system expansion, particularly new rail facilities, requires substantial capital investments, transit authorities are able to pool significant resources together to finance these projects. In addition to their direct public sources of revenue, transit authorities are able to apply for federal funding, which covers up to 80 percent of the actual capital acquisition costs. Beyond this federal contribution, transit agencies can also appeal to local governments to supply some or all of the additional 20 
percent local match required to fund the project. It is consequently possible (although unlikely) for a transit authority to fully finance a new capital project without using a dollar of dedicated agency funding.

Operations are more difficult to finance. While each dollar derived from ticket sales can be used to cover operations, transit service always operates at a loss. Nationally, farebox revenue accounts for only 35 percent of the cost of operating transit service (American Public Transportation Association 2003), and MARTA recovers only 38 percent of its operating costs (Georgia Department of Transportation 2003).

Because operating costs are not recovered in farebox revenues, transit operators are forced to identify alterative sources of revenue to cover the costs of operating transit service. Development projects, such as the Lindbergh development, have the ability to provide an important means of supplying this critical operating revenue.

For transit authorities, development projects, such as Lindbergh, are capital projects, similar to the construction of a new rail line or the provision of a new bus route. The revenues they generate, however, are operating dollars. As a consequence, even a development operating at a net fiscal loss can provide a transit authority with new funds that it can use to expand transit service (see Figure 4). To illustrate using the Lindbergh project as an example, in 2003 the Lindbergh project operates at a net loss of slightly more than $\$ 2$ million dollars (see Table 4 ). From a private sector perspective, the loss of $\$ 2$ million dollars is a real loss. This is not the case with MARTA's Lindbergh project. The loss for MARTA is solely in capital dollars, which are much easier to come by than operating dollars. Indeed, for a transit authority, all capital projects operate at a loss-undertaking financially unprofitable investments are central to its business approach. What is unique about development projects is that the losses are absorbed entirely on the capital side. While the project may operate at a net loss during 2003, it nevertheless provides MARTA with \$2.6 million dollars in new operating revenue-revenue that can be used to increase service frequencies and reestablish routes it was forced to eliminate during its current budget shortfall.

Although this finding would appear to have surface appeal to TOD advocates, it nevertheless leads to an unappealing conclusion. Transit agencies have a strong incentive to undertake financially unprofitable development projects, a problem that is exacerbated when transit agencies are running substantial operating deficits. Projects that are able to generate net positive operating revenues will com- 


\section{Figure 4. Using Development Projects to Shift Capital Dollars into Operating Dollars}

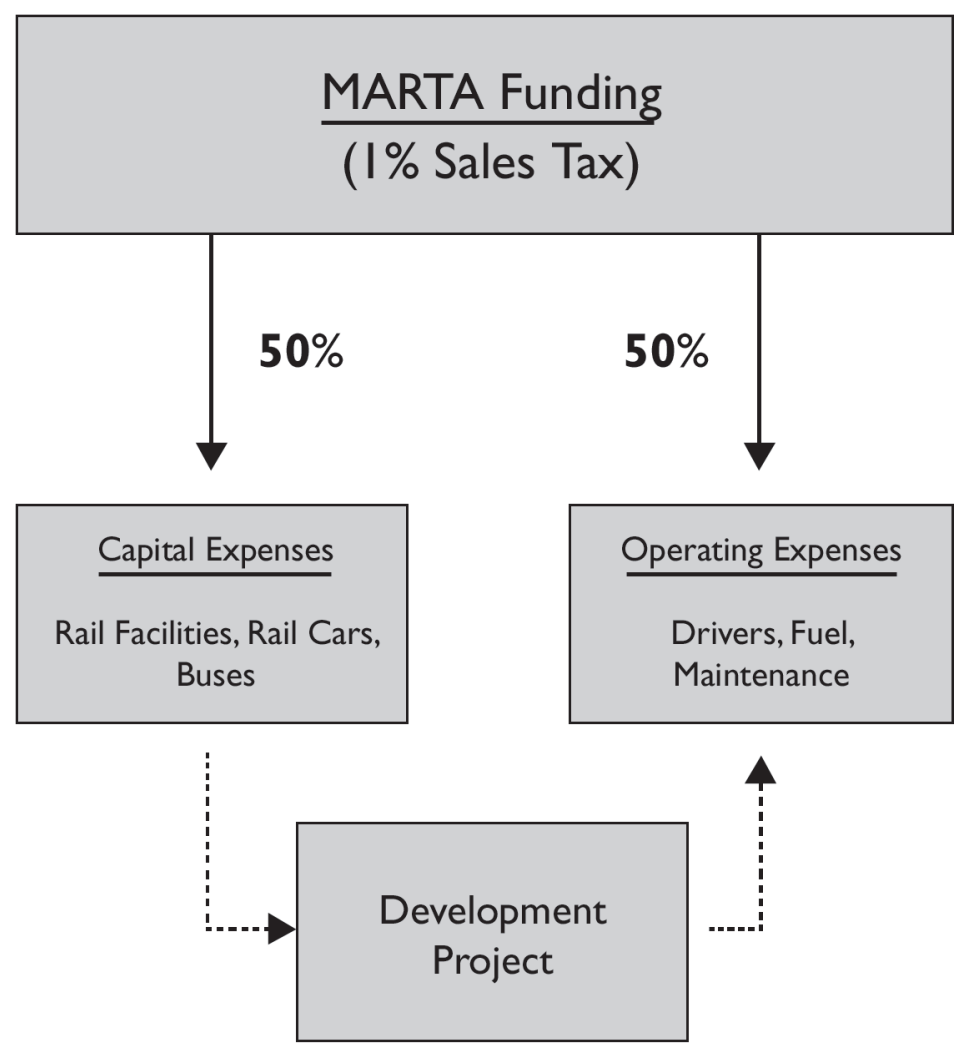

pete favorably with other projects, such as new transit lines, which run at a continuous operating loss. Since the costs are absorbed on the capital side, and the benefits realized on the operating side, the ultimate question for transit agencies is not whether a development makes sound financial sense, but instead, what capital losses are acceptable for new gains in operating revenue.

\section{Subsequent Revisions to the Transit Joint Development Policy}

While the FTA's 1997 Policy on Transit Joint Development permitted transit authorities to use development revenues from federally assisted properties for either capital or operating purposes, this freedom was later revoked when the policy was formally incorporated into the U.S. Code through the Transportation Equity Act for the 21st Century (TEA-21). ${ }^{10}$ TEA-21 indicated that "the net income from asset 
sales, uses, or leases (including lease renewals) under this section shall be used by the recipient to reduce the gross project cost of other capital projects carried out under this chapter" (49 U.S.C. 5334(g)). In other words, revenues coming from federally assisted properties could no longer be used to subsidize operations.

While this would seem to resolve the issues surrounding capital losses for operating gains, the likely result of this policy revision is simply to encourage transit agencies to undertake creative site configurations. Agencies seeking to increase their operating revenues have a powerful incentive to design these projects so that the revenue-generating uses are located not on the individual parcels that work best for the TOD as a whole, but instead on those parcels that provide the agency with the greatest fiscal flexibility in the use of revenues. Further, if operating revenues will not be generated through the development of the property, many agencies may be unwilling to even consider undertaking the complicated and uncertain federal review process needed to develop the property.

While there is no direct evidence to suggest that these considerations influenced the configuration of MARTA's Lindbergh development, it is nevertheless interesting that all of the project's revenue-generating uses-its commercial, retail, and residential elements - are located on properties acquired solely with local funds; the federally funded properties are being used for nonrevenue-generating uses, such as parking facilities and the relocation of the agency's headquarters. The Lindbergh development will consequently allow MARTA to apply the project's revenue to cover operating expenses, should MARTA choose to do so. ${ }^{11}$ Regardless of whether the Lindbergh site configuration was designed to circumvent federal requirements or simply a matter of coincidence, it is nevertheless clear that the decision to allow development on federally assisted properties, but to restrict the use of the revenue, does little more than to provide transit agencies with a barrier to optimizing the usefulness of a site.

\section{Conclusions}

The FTA's 1997 Policy on Transit Joint Development is a milestone for advocates of transit-oriented development. By relaxing federal restrictions on the use of transitarea properties, this policy gave transit agencies a powerful incentive to see station-area properties developed into TODs.

When one examines the actions MARTA undertook to realize this development, the potentially central role of transit agencies in the implementation of these 
projects emerges. As a public authority, transit agencies can synthesize many of the powers of the public sector to bring a project to fruition. First, transit agencies often have excess, and in many cases substantial landholdings surrounding their transit stations. The new ability to develop these properties can allow these agencies to bypass the land-assembly barriers that have previously made developing TODs difficult. Further, where land assembly is needed, transit agencies often have the ability to exercise eminent domain to acquire these properties, and may further be eligible to use federal funds for their acquisition.

Transit agencies can also overcome the second major barrier to TOD implementation: project finance. Transit agencies have the ability to use bond finance to cover the capital infrastructure costs that have made these projects undesirable to the private sector. In the case of the Lindbergh TOD, MARTA used \$81 million in bond finance to cover the streetscape, transit infrastructure, and structured parking costs of the development.

While this significant, high-risk investment would seem to merit a correspondingly high return, MARTA will receive only $\$ 153$ million over the 30-year bond repayment period, assuming all of its financial assumptions are met. Accounting for the time value of money, and applying a nominal 4 percent discount rate, the present value of MARTA's investment is only about $\$ 71$ million $-\$ 10$ million less than MARTA's initial investment.

The apportionment mechanisms applied to finance transit service explain MARTA's decision to undertake this development. While transit authorities were initially created as a means for the public to underwrite the provision of transit service, local and federal transit policies have been increasingly oriented toward reducing operating subsidies. This mixed policy mandate-whether to treat transit as a public good or to encourage it to be operationally efficient-currently makes transit agencies hard-pressed to identify projects that generate positive operating revenues that can be used to cover the costs of operating socially desirable, but financially unprofitable transit service.

TOD joint development projects, even while operating at a net fiscal loss, provide transit agencies with a means for transferring capital dollars into this much-needed operating revenue. Revenues from new riders, ground leases, and property sales can be applied toward covering operating costs (assuming the agency can circumvent more recent federal restrictions on the use of these revenues). Thus, even a development that is operating at a substantial net loss would appear to enhance 
overall transit performance since the development would generate new operating revenue that advances the agency's core mission-providing transit service.

\section{Acknowledgments}

The author wishes to thank Michael Meyer and David Sawicki for their invaluable review of earlier drafts of this article, as well as MARTA staff and management, who, while under severe time and budgetary constraints, were nevertheless extremely generous with their time. Thanks also to Dahshi Marshall, who supplied market information used in this research.

\section{Endnotes}

${ }^{1}$ The Common Grant Rule, which outlined federal policy regarding the disposition of property, relieved a transit agency of its obligation to the federal government for projects developed for transportation projects, but was unclear about what federal obligations, if any, would be required for federally funded properties used for real estate development. To avoid potential federal obligations, transit authorities have correspondingly limited their joint development ventures to projects built on the air rights of existing stations because the property is already being used for the intended transportation purpose, fulfilling the agency's obligation to the federal government under the Common Grant Rule.

${ }^{2}$ MARTA has roughly 280 acres of excess station-area landholdings.

${ }^{3}$ The concept of a public authority dates back to Elizabethan England. The term "authority" is derived from the Parliamentary act that authorized them, which began with the phrase "Authority is hereby given..." (Caro 1974, p. 615).

${ }^{4}$ MARTA's board of directors includes appointees from the City of Atlanta, Fulton, DeKalb, Gwinnett, and Clayton Counties, as well as members from the Georgia Department of Transportation, Georgia Regional Transportation Authority, State Properties Commission, and State Department of Revenue

${ }^{5}$ MARTA's police force, with 304 sworn officers, is the ninth largest in the State of Georgia (Source: MARTA).

${ }^{6}$ ITE's Trip Generation Handbook is the conventional reference used to estimate trip generation. This reference, however, pertains to automobile trips, and the method used to derive its trip generation estimates are regression results based on 
observations of single-use suburban developments, rather than the more urbanized development models represented by transit-oriented developments (Ewing and Dumbaugh 2001). To develop a more meaningful estimate of total trip generation, as well as to make the ridership assumptions transparent, I elected to develop independent estimates for each of the project elements that were consistent with the developmental mix of the project. My assumptions further account for travel variations associated with weekends, vacations, and holidays, factors not considered in the regression results shown in the ITE Trip Generation Handbook.

${ }^{7}$ While the Bellsouth component has what would appear to be a high transit capture rate, this assumption is supported by the characteristics of the development. As part of a mediation agreement with the neighborhood groups, BellSouth agreed to undersupply its on-site parking, forcing a third of its employees to use an alternate mode to work. To further encourage transit use, Bellsouth is combining transit pass subsidies with parking fees. Under the Metro plan, a monthly parking permit will cost $\$ 60$ per month, while a transit pass, after Bellsouth subsidies, will cost \$12. BellSouth's North Avenue building, built on the air rights of MARTA's North Avenue Station and employing a similar combination of parking restrictions and transit pass subsidies, currently has a 30 percent transit capture rate (Gilbert 2001; Vespermann 2002).

${ }^{8}$ MARTA provided me with a spreadsheet outlining their aggregate revenues through 2007, as well as its aggregate revenue for the build-out year of 2013. Revenues from ground leases through 2007 could consequently be determined by simply subtracting my estimates of condominium sales and ridership revenue from total revenues. To determine ground lease revenues for the 2007-2013 period, I estimated the sum of the difference between known ridership and sales revenues from the total revenues for the period, and then distributed it equally along each year of this period. While the distributions of ground lease revenues doesn't exactly match the development phasing cycle, this approach should not affect the accuracy of the results presented.

${ }^{9}$ To help minimize MARTA's current operating deficit, the state legislature recently adjusted this apportionment to allow MARTA to flex up to an additional 10 percent of state sales tax revenues for operating purposes.

${ }^{10}$ The federal government reauthorizes transportation funding through a multiyear legislative act. The two most recent transportation reauthorization packages, ISTEA and TEA-21, have been funded for six-year intervals. 
Journal of Public Transportation, Vol. 7, No. 3, 2004

${ }^{11}$ According to Paul Vespermann, former director of Transit-Related Developments, increasing system operating revenues is indeed the primary objective of this development (2002). 


\section{References}

American Public Transportation Association. 2003. Public transportation fact book. Washington DC: American Public Transportation Association.

Arrington, G. B. 2003. Light rail and the American city: State-of-the-practice for transit-oriented development. Transportation Research E-Circular E-C05:- 9th National Light Rail Transit Conference. Washington DC: Transportation Research Board.

Atlanta Journal Constitution. 2001. "MARTA to Discuss Tough Financial Choices," November 16.

Axelrod, Donald. 1992. Shadow government: The hidden world of public authorities and how they control \$1 trillion of your money. New York: John Wiley and Sons, Inc.

Boarnet, Marlon G., and Nicholas S. Compin. 1999. Transit-oriented development in San Diego county: The incremental implementation of a planning idea. Journal of the American Planning Association 65 (1) 80-95.

Belzer, Dena, and Gerald Autler. 2002. Transit Oriented Development: Moving From Rhetoric to Reality. Discussion paper prepared for the Brookings Institution Center on Urban and Metropolitan Policy and The Great American Station Foundation. Washington DC: The Brookings Institution

Caro, Robert A. 1974. The power broker. New York: Vantage Books.

Calthorpe, Peter. 1993. The next American metropolis: Ecology, community, and the American dream. New York: Princeton Architectural Press.

Cervero, Robert, Christopher Farrell, and Steven Murphy. 2002. Transit-oriented development and joint development in the United States: A literature review. Transit Cooperative Research Program Research Results Digest 52. Washington DC: Transportation Research Board.

Danielsen, Karen A., Robert E. Lang, and William Fulton. 1999. Retracting Suburbia: Smart Growth and the Future of Housing. Housing Policy Debate, 10, 3: $513-$ 540.

Duany, Andres, Elizabeth Plater-Zyberk, and Jeff Speck. 2000. Suburban nation: The rise of sprawl and the decline of the American dream. New York: North Point Press. 
Ewing, Reid, and Eric Dumbaugh. 2001. Internalizing travel by mixing land uses: A study of master-planned communities in South Florida. Transportation Research Record 1780: 115-120.

Federal Register. 1997. Federal Transit Administration Policy on Transit Joint Development. 62: 50, March 14, p. 12266.

Frank, Lawrence, Peter Engelke, and Tom Schmid. 2003. Health and Community Design. Washington DC: Island Press.

Georgia Department of Transportation. 2003. Georgia transit programs fact book. Atlanta: Georgia Department of Transportation.

Gilbert, Richard (Spokesperson for BellSouth). 2001. Telephone Interview, December 5 .

Glacel, Barbara Pate. 1983. Regional transit authorities: A policy analysis of Massachusetts. New York: Praeger Publishers.

Jackson, Kenneth T. 1985. Crabgrass frontier: The suburbanization of the United States. Oxford University Press: New York.

Leinberger, Christopher. 2001. Financing progressive development. Article prepared for the Brookings Institution Center for Urban and Metropolitan Policy and the Harvard University Joint Center for Housing Studies. Washington DC: The Brookings Institution.

MARTA. 1999. Development Application Submitted to the Federal Transit Administration, June 4.

MARTA. 2001. Transit oriented-development: The sMARTA way to development. Atlanta: The Metropolitan Atlanta Rapid Transit Authority.

Marx, Paul (Economist with the Office of Policy Development, Federal Transit Administration). 2002. Telephone Interview, January 15.

Porter, Douglas R. 1997. Synthesis of transit practice 20: Transit-focused development. Washington DC: Transportation Research Board, National Research Council.

Renne, John, and Jan Wells. 2002. State of the literature: Transit-oriented development. New Jersey: Vorhees Transportation Policy Institute. 
SMARTRAQ, Georgia Institute of Technology, Metro Atlanta Chamber of Commerce, and Robert Charles Lesser \& Co. 2001. Trends, implications \& strategies for balanced growth in the Atlanta region: Synthesis Report, SMARTRAQ.

Vespermann, Paul. 2001. "MARTA's Lindbergh City Center Project is Good for Metro Atlanta." Opinion Letter submitted to the Atlanta Business Chronicle. Atlanta Business Chronicle. January 26.

Vespermann, Paul (Director of Transit-Related Development, MARTA). 2002. Telephone Interview, February 26.

Walsh, Annmarie Hauck. 1978. The public's business: The politics and practices of government corporations. Cambridge, MA: MIT Press.

Warner, Sam Bass. 1978. Streetcar suburbs: The process of growth in Boston (18701900). Harvard University Press: Cambridge, MA.

Yin, Robert K. 2003. Case study research: Design and methods, 3rd ed. Thousand Oaks: Sage Press.

\section{About the Author}

Eric Dumbaugh (edumbaugh@aol.com) is a doctoral candidate in the School of Civil and Environmental Engineering at the Georgia Institute of Technology. He holds joint master's degrees in city and regional planning and civil engineering, also from Georgia Tech. His recent research focuses on nonmotorized travel, performance measurement, and safety-conscious planning. His dissertation, scheduled for completion in 2005, examines strategies for incorporating context-sensitive solutions into the design practices of state and local departments of transportation. 